This is an Open Access article, distributed under the terms of the Creative Commons Attribution licence (http://creativecommons.org/licenses/by/4.0/), which permits unrestricted re-use, distribution, and reproduction in any medium, provided the original work is properly cited.

\title{
Detecting Mobility in Early Iron Age Thessaly by Strontium Isotope Analysis
}

\author{
Eleni Panagiotopoulou ${ }^{1}$, Janet Montgomery ${ }^{2}$, Geoff Nowell ${ }^{3}$, \\ Joanne Peterkin ${ }^{3}$, Argiro Doulgeri-Intzesiloglou ${ }^{4}$, Polixeni Arachoviti ${ }^{4}$, \\ Stiliani Katakouta ${ }^{5}$ and Fotini Tsiouka ${ }^{6}$ \\ ${ }^{1}$ Institute of Archaeology, University of Groningen, The Netherlands \\ ${ }^{2}$ Department of Archaeology, Durham University, UK \\ ${ }^{3}$ Department of Earth Sciences, Durbam University, UK \\ ${ }^{4}$ Ephorate of Antiquities of Magnesia, Hellenic Ministry of Culture, Volos, Greece \\ ${ }^{5}$ Ephorate of Antiquities of Larisa, Hellenic Ministry of Culture, Larisa, Greece \\ ${ }^{6}$ Ephorate of Antiquities of Karditsa, Hellenic Ministry of Culture, Karditsa, Greece
}

This article presents evidence of population movements in Thessaly, Greece, during the Early Iron Age (Protogeometric period, eleventh-ninth centuries BC). The method we employed to detect non-local individuals is strontium isotope analysis $\left({ }^{87} \mathrm{Sr}{ }^{86} \mathrm{Sr}\right)$ of tooth enamel integrated with the contextual analysis of mortuary practices and osteological analysis of the skeletal assemblage. During the Protogeometric period, social and cultural transformations occurred while society was recovering from the disintegration of the Mycenaean civilization (twelfth century BC). The analysis of the cemeteries of Voulokaliva, Chloe, and Pharsala, located in southern Thessaly, showed that non-local individuals integrated in the communities we focused on and contributed to the observed diversity in burial practices and to the developments in the formation of a social organization.

Keywords: Early Iron Age, Greece, strontium isotope analysis, population mobility, Thessaly

\section{INTRODUCTION}

This article consists of an investigation of population movements in Thessaly during the post-Mycenaean period (Early Iron Age, tenth-ninth centuries $\mathrm{BC}$ ), using strontium isotope analysis of human tooth enamel. Previous research on this period has primarily focused on the analysis of ancient historical sources and archaeological data (Desborough, 1964; Snodgrass, 2000; Lemos, 2002; Dickinson, 2006; Morris, 2007). In more recent years, various analytical methods have been employed to investigate diet, chronology, and metal and ceramic production in Early Iron Age Greece (Papathanasiou, 2013; Toffolo et al., 2013; Rückl, 2014; Orfanou, 2015; Panagiotopoulou \& Papathanasiou, 2015; Triantaphyllou, 2015). While strontium isotope analysis has been previously conducted on Greek assemblages (Richards, 2008; Nafplioti, 2011), this is the first time this method has been employed to investigate anthropological remains from the Early Iron Age in Greece.

The region of Thessaly was chosen because it is traditionally considered as 
forming the northern border of the Mycenaean world and, thus, was affected in the same way as the rest of the mainland by the disintegration of the Mycenaean civilization (thirteenth-twelfth centuries $\mathrm{BC}$ ). The collapse of the palatial system resulted in a deep crisis; it prompted the breakdown of a stratified society, a decline in social institutions, and a social regression (Dickinson, 2006). In the subsequent Sub-Mycenaean (eleventh century BC) and Protogeometric (tenth and ninth centuries $\mathrm{BC}$ ) periods, changes occurred in social organization, in trade and interaction, in production and technology, in material culture, and in burial practices (Lemos, 2002).

In the Protogeometric period, the first signs of important social developments become visible (Morris, 2007). The distribution of pottery and metalwork indicates that these regions had contacts and interacted either inside or outside Thessaly (Rückl, 2014; Lis et al., 2015). New cemeteries were established, but pre-existing Mycenaean ones were also still in use. Mycenaean funerary practices, such as multiple burials in tholoi, were still present alongside single burials in cists, a practice that spread very extensively in the Early Iron Age and is considered to have largely replaced the traditional burial forms (Dickinson, 2006).

Many theories have been put forward to explain the changes and the mosaic in the burial record of the post-Mycenaean period. The notion, based on an interpretation of the work of ancient writers, of a large-scale migration of hostile groups from northern areas of Greece and the Balkans was posited to explain the sudden and widespread change (Desborough, 1972). This idea lost ground as new evidence suggested that it was a deterioration of living conditions that led to a gradual transformation of the social organization of Early Iron Age communities (Whitley,
1991; Morris, 2007). Another hypothesis attributes the changes to a shift from sedentary agriculture to pastoralism (Snodgrass, 2006); studies into the health status of Early Iron Age populations, which was considered to have improved compared to the Late Bronze Age, suggested they consumed larger amounts of meat (Morris, 2007). However, the lack of sufficient archaeozoological studies in this period makes it problematic to follow this line of enquiry further. More recently, population movement models have once again come to the fore as an explanation. These models propose that small-scale movements of groups or individuals within and without the old palatial territories explain the cultural and social changes observed (Snodgrass, 2000; Lemos, 2002; Coldstream, 2003; Morris, 2007; Georganas, 2009).

Several major questions currently dominate the scholarly discussions of Early Iron Age Greece:

A. Can we detect whether population movements were associated with changes in the mortuary record?

B. If so, were they at the level of a population or did they involve individuals or small groups (such as families) moving from one place to another?

Many approaches have been devised to detect movements of groups, such as cultural, technological, and linguistic diffusion, but arguments against such interpretations have been put forward due to ambiguities or biases in the archaeological data or lack of substantial evidence (Hall, 1997). Here, we aim to examine the movements of people in the Early Iron Age by integrating strontium isotope analysis of human tooth enamel with the contextual analysis of mortuary data.

Our study focuses on the mortuary evidence from three sites in Thessaly, which occupy significant locations and exhibit substantial variation in funerary practices: 
the cemetery of Chloe, the cemetery of Voulokaliva in Halos, and the cemeteries of Pharsala (Figure 1).

\section{Archaeological Context}

The cemetery of Chloe is one of the burial grounds of Pherae, a town occupied continuously from the Late Neolithic (4500$3200 / 3000$ BC) to the Roman period (first century BC to fourth century AD) (DoulgeriIntzesiloglou, 1994; Doulgeri-Intzesiloglou \& Arachoviti, 2006; Georganas, 2008). The cemetery is located in eastern Thessaly, on a plain north-west of the Pagasetic Gulf (Doulgeri-Intzesiloglou, 1994, 1996; Arachoviti, 2000; Doulgeri-Intzesiloglou \& Arachoviti, 2006; Georganas, 2008) (Figure 1). Eight tholoi were discovered, all of the same type; which follows that of the Mycenaean predecessors, but are smaller (Arachoviti, 2000) and located close to each other. This study focuses on two of the eight tholoi (EII, ZI). These two tholoi contained multiple inhumations of males, females, and subadults older than five years (Panagiotopoulou et al., forthcoming).

The cemetery of Voulokaliva is one of the three cemeteries of Halos in south-eastern
Thessaly (Figure 1), with a period of use from the later Bronze Age (c. 1300-1100 BC) to Hellenistic times (c. 300-265 BC) (Reinders, 2003; Malakasioti, 2006). Voulokaliva is located on the western coast of the Pagasetic Gulf near important maritime routes and along land routes that connected it with the southern and northern Greek mainland (Stissi et al., 2004). The individuals were buried mainly in simple pits and cists, but a circular construction, probably an imitation of a tholos tomb, was also found. Adjacent to the clusters of burials in the cemetery, scattered graves have been found throughout the area, but, because the cemetery was a rescue excavation, its full extent and perimeter is not (yet) known. The graves included single and double inhumations of males, females, and subadults of all ages (Panagiotopoulou et al., 2016).

Pharsala is located in southern Thessaly, near routes to western Thessaly and Epirus through Mount Pindos. Two burial grounds have been excavated (Tziafalias \& Batziou-Efstathiou, 2010; Katakouta, 2012): one (Site 1) is a northwards extension of the Mycenaean cemetery, while the other (Site 2) is a rather distant burial ground (Figure 1). Site 1 had single or multiple inhumations of

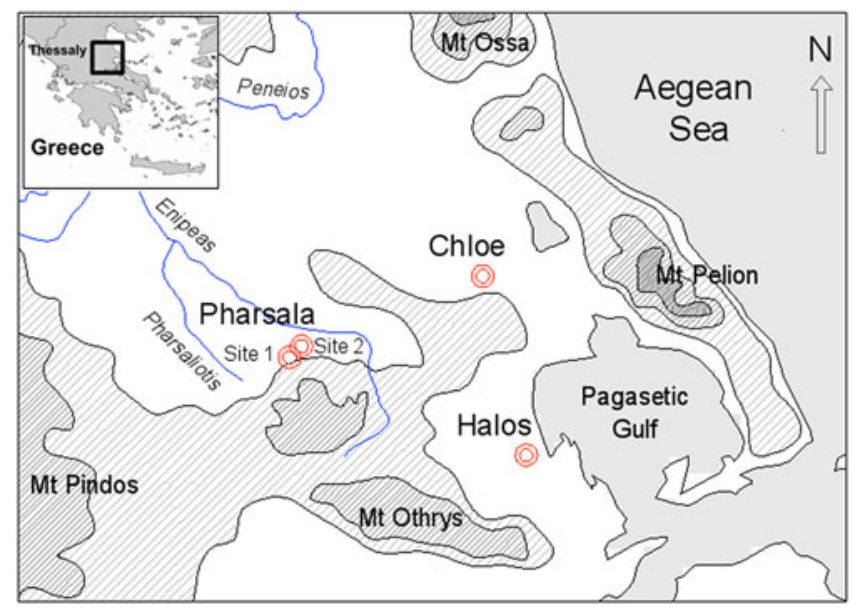

Figure 1. Location map showing Greece and Thessaly. 
males and females, single inhumations of subadults of all ages, and a few cremations. The tomb types are pits, cists, burial enclosures, tholoi, and a tumulus. Site 2, located approximately $6 \mathrm{~km}$ to the north-east of the first cemetery, consists of two tholoi covering only adults (Panagiotopoulou et al., forthcoming). Details of the osteological analysis of the human remains used in this article are available in Panagiotopoulou et al. (2016) and Panagiotopoulou et al. (forthcoming).

\section{Variation in Burial Practices}

The contextual analysis of burial practices defines the context in which the burial forms developed, in our case the different tomb types, tomb distribution patterns, burial treatment, age, and sex of the individuals.

The analysis has indicated funerary patterns and variations, which can be attributed to social differentiation (Panagiotopoulou et al., 2016; Panagiotopoulou et al., forthcoming) but also to the presence of nonlocal individuals. Here, we focus on aspects where population movements may have caused such differentiation. These aspects are: a) the spatial organization in different burial locations used by the same community; b) the co-existence of clustered and non-clustered graves in the same cemetery; and c) the different grave types, such as simple graves with single burials against complex tomb constructions with multiple burials.

The cemetery of Chloe included mainly tholos tombs with multiple burials, although a few cist graves were also present. The contemporaneous site of Voulokaliva in Halos mainly comprised single burials in simple cists. Pharsala, on the other hand, is the cemetery showing the greatest diversity. The variety of different tomb types, treatment, and burial locations was attributed to the same community. Furthermore, the practice of excluding young subadults (under four years old) from receiving formal burial in the Early Iron Age, a practice considered to be Mycenaean, was only attested in a few cases, such as at the tholoi of Chloe (Panagiotopoulou et al., 2016; Panagiotopoulou et al., forthcoming).

Chloe appears to be a cemetery where traditional burial practices continued to be performed, whereas Voulokaliva and Pharsala incorporated more innovative practices. The community of Voulokaliva adopted only simple forms, while the cemetery of Pharsala developed in a more complex manner, with innovation and tradition present alongside each other in a more evident way.

The questions initially formulated can now be turned into more targeted and specific questions:
A. Could differences in burial locations/ clusters indicate groups or individuals of different origin(s)? introduced by individuals who had moved to these communities from other regions, or did the need for social change drive the local popula- tion towards this choice?
B. Could innovative practices have been

These questions were addressed through the application of strontium isotope analysis to investigate whether, and in what proportion, non-local individuals were present at each site.

\section{The Environmental Context of Greece and Thessaly}

Greece lies at the southern edge of the Balkan Peninsula. It has a varied terrain, with a long coastline and mountains alternating with plains. The mountains can be very high with rounded summits, and erosion makes relics of the old landscape 
visible. The lowlands are coastal plains or inland basins that were depressed and uplifted again (Darby, 1944; Danalatos, 1992; Higgins \& Higgins, 1996).

Thessaly lies in the eastern part of the central Greek mainland (Figure 1). The Thessalian bedrock is mainly composed of limestones, dolomites, schists, and flysch of Triassic age (252.17-208.8 million years ago). During the Oligocene (36.623.7 million years ago) and Miocene (23.7-5.3 million years ago), Thessaly was a shallow sea and, later, in the early Pliocene (5.3-1.6 million years ago), an extensive lake. Tectonic activity in the Pleistocene created grabens, which accumulated lacustrine deposits.

Thessaly's depression is surrounded by mountain ranges: the mountain chain of Olympos-Ossa-Pelion is in the north and east and is a Neogene horst composed of Pelagonian ophiolites, gneiss, schist, and metamorphosed sedimentary and volcanic rocks. Pelion, the southern end of the range and the nearest to the site of Chloe, is mainly composed of schist, but marble is also present on the northern side of the mountain. The Pindos range is in the west of Thessaly. The Pindos zone has been a deep ocean basin with limestone accumulations, which was later filled with flysch sediments. Finally, Mount Othrys, which is the nearest to the cemetery of Voulokaliva, demarcates the southern borders of Thessaly. It consists of limestone, Neogene sediments, and marble (Danalatos, 1992; Higgins \& Higgins, 1996).

\section{Materials ANd Method}

\section{Enamel and environmental samples}

For the purpose of this study, we collected human tooth enamel and environmental samples. We sampled non-diagnostic of pathologies human teeth, preferably loose and not attached to the mandible or maxilla but evidently associated with specific individuals. The number of samples from each site is as follows: ten from Chloe, thirteen from Voulokaliva, and thirteen from Pharsala (Table 1). Environmental sampling covered the geological formations that could have contributed to the strontium intake by humans and animals, as shown in Table 2.

The environmental samples (snail shells and water samples) were obtained from the wider area surrounding the cemeteries. We attempted to cover areas of possible land exploitation for plant farming and animal breeding as well as water sources. This sampling provided information on the range of bioavailable strontium that characterizes the soil and water end-members of the cemetery regions or regions of comparable geology. At Chloe the sampling circle around the cemetery was approximately 5 $\mathrm{km}$ in diameter. Sampling stopped at physical boundaries-i.e. where the same geological formation was extended for long distances and where access to areas was hindered by boundaries such as mountains (Figure 2). The area of Halos was sampled within a diameter of approximately $10 \mathrm{~km}$. Again, a mountain, the sea, and extended geological formations were the boundaries to further sampling (Figure 3). Pharsala was encircled by a diameter of approximately $9 \mathrm{~km}$, using parameters similar to those chosen for the previous sites (Figure 4).

Several ways of establishing the local baseline have been developed since the first use of strontium isotope analysis in archaeology. Statistical analyses of human isotope ratios and analysis of soils, plants, waters, and modern animals with limited foraging distance, such as rodents and snail shells, have all been used to better define the local strontium baseline (Price et al., 1994, 2002; Wright, 2005; Hartman \& Richards, 2014). Here, we have used snail shells and water samples because both are 
Table 1. Sr isotope ratios of human enamel samples and dentine from the sites of Chloe, Voulokaliva, and Pharsala. Samples were analysed during two analytical sessions. The reproducibility of the NBS987 standard in the two sessions is given below. The superscript number by the ${ }^{87} \mathrm{Sr}{ }^{86} \mathrm{Sr}$ ratio relates the sample to the relevant analytical session.

1. Average ${ }^{87} \mathrm{Sr}{ }^{86} \mathrm{Sr}$ for NBS987: 0.710278 $\pm 23(32 \mathrm{ppm}, 2 \mathrm{SD} n=10)$

2. Average ${ }^{87} \mathrm{Sr}{ }^{86} \mathrm{Sr}$ for NBS987: $0.710264 \pm 17(24 \mathrm{ppm}, 2 \mathrm{SD} n=11)$

\begin{tabular}{|c|c|c|c|c|c|}
\hline Site & Sample number & ${ }^{87} \mathrm{Sr} /{ }^{86} \mathrm{Sr}$ norm & 2SE & Sr concentration (ppm) & $(1 / \mathrm{Sr})^{*} 10^{3}$ \\
\hline Chloe & $\mathrm{C} / \mathrm{E}-\mathrm{th} 2 / \mathrm{cr} 2$ & $0.7091^{2}$ & 0.000021 & 93 & 11 \\
\hline Chloe & $\mathrm{C} / \mathrm{E}-\mathrm{th} 2 / \mathrm{cr} 3$ & $0.7094^{2}$ & 0.000020 & 113 & 9 \\
\hline Chloe & $\mathrm{C} / \mathrm{E}-\mathrm{th} 2 / \mathrm{o} 4$ & $0.7089^{2}$ & 0.000018 & 92 & 11 \\
\hline Chloe & $\mathrm{C} / \mathrm{E}-\mathrm{th} 2 / \mathrm{cr} 6$ & $0.7091^{2}$ & 0.000017 & 120 & 8 \\
\hline Chloe & $\mathrm{C} / \mathrm{E}-\mathrm{th} 2 / \mathrm{cr} 7$ & $0.7091^{2}$ & 0.000013 & 104 & 10 \\
\hline Chloe & $\mathrm{C} / \mathrm{Z}$-th1/cr1 & $0.7091^{2}$ & 0.000017 & 133 & 8 \\
\hline Chloe & C/Z-th1/cr3 & $0.7091^{2}$ & 0.000019 & 107 & 9 \\
\hline Chloe & $\mathrm{C} / \mathrm{Z}-\mathrm{th} 1 / \mathrm{cr} 4$ & $0.7091^{2}$ & 0.000021 & 87 & 12 \\
\hline Chloe & $\mathrm{C} / \mathrm{Z}$-th1/cr8 & $0.7092^{2}$ & 0.000018 & 121 & 8 \\
\hline Chloe & $\mathrm{C} / \mathrm{Z}$-th1/cr10 & $0.7089^{2}$ & 0.000020 & 79 & 13 \\
\hline Voulokaliva & $\mathrm{HaVo} / \mathrm{e}-\mathrm{c} 5$ & $0.7091^{1}$ & 0.000018 & 95 & 11 \\
\hline Voulokaliva & $\mathrm{HaVo} / \mathrm{e}-\mathrm{cc} 8 / \mathrm{ind} 1$ & $0.7087^{1}$ & 0.000018 & 92 & 11 \\
\hline Voulokaliva & $\mathrm{HaVo} / \mathrm{e}-\mathrm{c} 12 / \mathrm{ind} 1$ & $0.7090^{1}$ & 0.000019 & 72 & 14 \\
\hline Voulokaliva & $\mathrm{HaVo} / \mathrm{e}-\mathrm{p} 65$ & $0.7090^{1}$ & 0.000016 & 55 & 18 \\
\hline Voulokaliva & $\mathrm{HaVo} / \mathrm{e}-\mathrm{p} 66$ & $0.7091^{1}$ & 0.000015 & 81 & 12 \\
\hline Voulokaliva & $\mathrm{HaVo} / \mathrm{e}-\mathrm{c} 72$ & $0.7089^{1}$ & 0.000018 & 61 & 16 \\
\hline Voulokaliva & $\mathrm{HaVo} / \mathrm{w}-\mathrm{c} 7 / \mathrm{ind} 1$ & $0.7079^{1}$ & 0.000016 & 132 & 8 \\
\hline Voulokaliva & $\mathrm{HaVo} / \mathrm{w}-\mathrm{c} 7 /$ ind 2 & $0.7085^{1}$ & 0.000022 & 106 & 9 \\
\hline Voulokaliva & $\mathrm{HaVo} / \mathrm{w}-\mathrm{c} 11 / \mathrm{ind} 1$ & $0.7089^{1}$ & 0.000019 & 56 & 18 \\
\hline Voulokaliva & $\mathrm{HaVo} / \mathrm{w}-\mathrm{c} 11 /$ ind 2 & $0.7092^{1}$ & 0.000014 & 72 & 14 \\
\hline Voulokaliva & $\mathrm{HaVo} / \mathrm{w}-\mathrm{c} 13$ & $0.7092^{2}$ & 0.000020 & 75 & 13 \\
\hline Voulokaliva & $\mathrm{HaVo} / \mathrm{w}-\mathrm{c} 21$ & $0.7091^{2}$ & 0.000016 & 129 & 8 \\
\hline Voulokaliva & $\mathrm{HaVo} / \mathrm{w}-\mathrm{p} 31$ & $0.7089^{2}$ & 0.000026 & 44 & 23 \\
\hline Pharsala & F/Ep-th1 & $0.7091^{1}$ & 0.000018 & 77 & 13 \\
\hline Pharsala & F/Ep-th2/ind2 & $0.7091^{1}$ & 0.000020 & 86 & 12 \\
\hline Pharsala & $\mathrm{F} / \mathrm{Ep}$-th2/ind1 & $0.7091^{1}$ & 0.000015 & 108 & 9 \\
\hline Pharsala & $\mathrm{F} / \mathrm{Ep}$-th2/secA/ind 1 & $0.7091^{1}$ & 0.000016 & 78 & 13 \\
\hline Pharsala & F/Ep-th2/secB & $0.7091^{1}$ & 0.000016 & 76 & 13 \\
\hline Pharsala & F/Od- be18/ind1 & $0.7088^{1}$ & 0.000018 & 83 & 12 \\
\hline Pharsala & F/Od-th20 & $0.7088^{1}$ & 0.000016 & 83 & 12 \\
\hline Pharsala & F/Od-be28/south & $0.7094^{1}$ & 0.000015 & 153 & 7 \\
\hline Pharsala & F/Od-c25 & $0.7092^{1}$ & 0.000010 & 165 & 6 \\
\hline Pharsala & F/Per-th1/ind3 & $0.7087^{1}$ & 0.000020 & 69 & 15 \\
\hline Pharsala & F/Per-c4 & $0.7087^{1}$ & 0.000018 & 71 & 14 \\
\hline Pharsala & F/Per-c5 & $0.7087^{1}$ & 0.000022 & 94 & 11 \\
\hline Pharsala & F/Per-c8 & $0.7080^{1}$ & 0.000018 & 187 & 5 \\
\hline Double & F/Od-be18/ind1 & $0.7088^{2}$ & 0.000019 & 71 & 14 \\
\hline Double & $\mathrm{HaVo} / \mathrm{w}-\mathrm{c} 7 /$ ind 1 & $0.7090^{2}$ & 0.000014 & 135 & 7 \\
\hline
\end{tabular}


Table 1. (Cont.)

\begin{tabular}{|c|c|c|c|c|c|}
\hline Site & Sample number & ${ }^{87} \mathrm{Sr} /{ }^{86} \mathrm{Sr}$ norm & $2 \mathrm{SE}$ & Sr concentration (ppm) & $(1 / \mathrm{Sr})^{*} 10^{3}$ \\
\hline Dentine & F/Od-be18/ind1 & $0.7082^{2}$ & 0.000016 & 112 & 9 \\
\hline Dentine & $\mathrm{HaVo} / \mathrm{w}-\mathrm{c} 21$ & $0.7083^{2}$ & 0.000018 & 91 & 11 \\
\hline Dentine & C/E-th2/cr2 & $0.7100^{2}$ & 0.000018 & 268 & 4 \\
\hline
\end{tabular}

suitable for Thessaly, based on the region's environmental characteristics.

Snail shells represent the different geological formations in the areas around the cemeteries. Snails are suitable proxies for this study for two reasons: a) their limited foraging range reflects the averaged local plants consumed by the snail and the local strontium isotope ratio; and b) Thessaly is a low-rainfall region receiving approximately $400-800 \mathrm{~mm}$ annual rainfall and thus the strontium incorporated into the snail shell is not diluted (Evans et al., 2009).

\section{Strontium isotope analysis}

Strontium isotope analysis of tooth enamel was employed to address the research questions presented above regarding the Early Iron Age communities. Strontium is an element that is incorporated into the human body, primarily the skeleton, through diet and is strongly related to the geological and geographical environment where the food was produced. Strontium in the biosphere derives from the underlying bedrock and its isotope ratios depend on the lithological composition and the age of the rock. Weathering and erosion of the rocks and subterranean water movements transfer the strontium to the soil, and into the human food chain via the consumption of plants by animals and humans (Stallo et al., 2010).

Strontium is incorporated into both bone and teeth, but the most suitable tissue has proved to be tooth enamel for two major reasons. First, tooth enamel is dense, inert, non-porous, and resistant to post- mortem contamination (Price et al., 2002). Second, teeth are formed during childhood, and tooth enamel, an acellular and avascular tissue, does not remodel subsequently and, thus, is regarded as an archive of childhood exposure. Therefore, by studying strontium isotopes in tooth enamel we gain information on the geological environment from which individuals obtained their food during childhood. If an individual relocated in later life to a different geological terrain, the strontium isotope ratio of their burial place and that of their tooth enamel should be distinguishable (Montgomery, 2010).

\section{Laboratory Procedure}

Samples for $\mathrm{Sr}$ isotope analysis were prepared and analysed at the Arthur Holmes Isotope Geology Laboratory, Department of Earth Sciences, Durham University. Enamel samples were removed from each tooth using dental burs and saws, cleaned of all surfaces and adhering dentine and sealed in microtubes. In order to characterize the environment at each of the three sites, samples of c. $50 \mathrm{mg}$ from the shells of land snails and water samples of $30 \mathrm{ml}$ were collected from streams and seawater.

The pre-cleaned enamel chips $(0.01 \mathrm{~g}-$ $0.1 \mathrm{~g}$ ) were weighed into clean Teflon beakers and dissolved in $1 \mathrm{ml}$ Teflon distilled (TD) $16 \mathrm{M} \mathrm{HNO}_{3}$, dried down, and re-dissolved in $0.5 \mathrm{ml} \mathrm{TD} 3 \mathrm{M} \mathrm{HNO}_{3}$. Sr was extracted from the sample matrix as a fraction eluted from an Eichrom Sr-Spec exchange resin column.

The Sr fraction, eluted from the column in $0.4 \mathrm{mls} \mathrm{MQ} \mathrm{H}_{2} \mathrm{O}$, was acidified with 
Table 2. Sr isotope values of environmental samples from the sites of Chloe, Voulokaliva, and Pharsala. Average ${ }^{87} \mathrm{Sr}{ }^{86} \mathrm{Sr}$ for NBS987 standard during analytical session for environmental samples: $0.710278 \pm 23(32 \mathrm{ppm}, 2 S D \mathrm{n}=10)$. The geological periods and formations where the samples have been collected are also presented.

\section{Environmental samples}

\begin{tabular}{|c|c|c|c|c|c|}
\hline Site & $\begin{array}{l}\text { Sample } \\
\text { name }\end{array}$ & 2SD & $\begin{array}{l}\text { Sample } \\
\text { type }\end{array}$ & Geological formations & Period \\
\hline
\end{tabular}

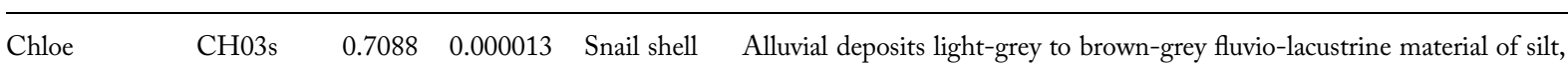

clay, and very little coarser material deposited in the Voiviis (Karla) lake basin, deposits on plains, open towards the sea, and small interior basins of clay, sand, and pebbles, torrential deposits, torrential terraces material, and eluvial mantle material.

Chloe CH05w $0.7086 \quad 0.000018$ Wate

Alluvial deposits light-grey to brown-grey fluvio-lacustrine material of silt, clay and very little coarser material deposited in the Voiviis (Karla) lake basin, deposits on plains, open towards the sea, and small interior basins of clay, sand, and pebbles, torrential deposits, torrential terraces material, and eluvial mantle material. Near the formation: Middle Triassic/Upper Jurassic, marbles which constitute the regular upwards evolution of the Neopaleozoic-Lower Middle Triassic formations with a locally intercalated horizon consisting of calcite schists, cipolins, and muscovite schists with metabasite intercalations. Small bauxite occurrences.

\section{Chloe $\quad$ CH09s $\quad 0.7089 \quad 0.000015$ Snail shell ol: olistholiths of diabasic-dioritic rocks}

In the Velestino area in the lower parts of the flysch, olistoliths and olistostromes of various lithological composition are present, with limestones, dolomites, serpentinites, pyroxenites, diabasic rocks, cherts, and others of a total thickness of up to $c .150 \mathrm{~m}$. Locally the flysch unconformably overlies the underlying Upper Cretaceous limestones.

fg: flysch consisting of fine- to medium-grained sandstones and in places, towards the upper parts, of coarse-grained sandstones, with the main minerals being quartz, feldspar, muscovite, sericite, and calcite with intercalations of pelites, laminated in places, conglomerates, and sandy conglomerates.

Chloe

$\mathrm{CH} 12 \mathrm{~s}$

$0.7095 \quad 0.000017 \quad$ Snail shell

Voulokaliva

Halos
HL01s

$0.7078 \quad 0.000017 \quad$ Snail shell
Fluvioterrestrial formations: red clays, clayey, sandy material of low cohesion, with dispersed rounded and angular pebbles, or coarse-grained element of various lithological composition, and breccio-conglomerates.

Quaternary undivided, diluvium and alluvium. Clays, sands, gravels, talus (scree). Coastal conglomerates. Continental deposits. The site is coastal.
Quaternary/Holocene

Quaternary/Holocene

Pelagonian Zone - Lower Tectonic Unit - Middle Senonian/ Maestrichtian/Paleocene

Pelagonian Zone - Lower Tectonic Unit - Middle Senonian/ Maestrichtian/Paleocene

Pontian - Pliocene - Lower Pleistocene

Quaternary 
Table 2. (Cont.)

\begin{tabular}{|c|c|c|c|c|c|c|}
\hline \multicolumn{7}{|c|}{ Environmental samples } \\
\hline Site & $\begin{array}{l}\text { Sample } \\
\text { name }\end{array}$ & Sr & 2SD & $\begin{array}{l}\text { Sample } \\
\text { type }\end{array}$ & Geological formations & Period \\
\hline $\begin{array}{l}\text { Voulokaliva } \\
\text { Halos }\end{array}$ & HL04s & 0.7080 & 0.000015 & Snail shell & $\begin{array}{l}\text { Quaternary undivided, diluvium and alluvium. Clays, sands, gravels, talus. } \\
\text { Coastal conglomerates. Continental deposits. }\end{array}$ & Quaternary \\
\hline $\begin{array}{l}\text { Voulokaliva } \\
\text { Halos }\end{array}$ & HL05w & 0.7086 & 0.000018 & Water & $\begin{array}{l}\text { Quaternary undivided, diluvium and alluvium. Clays, sands, gravels, talus. } \\
\text { Coastal conglomerates. Continental deposits. }\end{array}$ & Quaternary \\
\hline $\begin{array}{l}\text { Voulokaliva } \\
\text { Halos }\end{array}$ & HL14s & 0.7088 & 0.000016 & Snail shell & $\begin{array}{l}\text { Partly or entirely metamorphosed formation of flysch (shales, sandstones, } \\
\text { conglomerates, and intercalated limestones). Phyllites, sandstones, layers } \\
\text { of black crystalline limestone. } \\
\text { Fossils scarce. }\end{array}$ & Upper Cretaceous \\
\hline $\begin{array}{l}\text { Voulokaliva } \\
\text { Halos }\end{array}$ & HL15w & 0.7079 & 0.000013 & Water & $\begin{array}{l}\text { Neogene undivided. Mostly Pliocene. Marls, clays, gravels, sandstones, } \\
\text { conglomerates, marly limestones. Neogene freshwater deposits with } \\
\text { lignites. Fossils. } \\
\text { Adjacent to the formation: Quaternary undivided, diluvium and alluvium. } \\
\text { Clays, sands, gravels, talus. Coastal conglomerates. } \\
\text { Continental deposits. }\end{array}$ & Neogene/Pliocene \\
\hline $\begin{array}{l}\text { Voulokaliva } \\
\text { Halos }\end{array}$ & HL18s & 0.7089 & 0.000016 & Snail shell & $\begin{array}{l}\text { Partly or entirely metamorphosed formation of flysch (shales, sandstones, } \\
\text { conglomerates, and intercalated limestones\}. Phyllites, sandstones, layers } \\
\text { of black crystalline limestone. } \\
\text { Fossils scarce. } \\
\text { Between two formations. The second is metamorphosed thin-bedded or } \\
\text { compact limestone of Upper Cretaceous age, with phyllites and breccias } \\
\text { On the coastline. }\end{array}$ & Neogene/Pliocene \\
\hline $\begin{array}{l}\text { Voulokaliva } \\
\text { Halos }\end{array}$ & HL18w & 0.7092 & 0.000018 & Sea water & Same as above & Same as above \\
\hline Pharsala & FS03s & 0.7084 & 0.000014 & Snail shell & Alluvium & Holocene \\
\hline Pharsala & FS03w & 0.7082 & 0.000017 & Water & Alluvium & Holocene \\
\hline Pharsala & $\mathrm{FS} 04 \mathrm{~s}$ & 0.7082 & 0.000021 & Snail shell & Alluvium & Holocene \\
\hline Pharsala & FS04w & 0.7085 & 0.000016 & Water & Alluvium & Holocene \\
\hline Pharsala & FS07w & 0.7078 & 0.000014 & Water & $\begin{array}{l}\text { Ks: micro-brecciated limestone. Maybe under that cortege ophiolite. } \\
\text { Adjacent to Holocene cônes de dejections torrentiels }\end{array}$ & $\begin{array}{l}\text { Pelagonian Zone: Upper and Middle } \\
\text { Cretaceous/Jurassic-Triassic (?) }\end{array}$ \\
\hline Pharsala & FS11s & 0.7088 & 0.000015 & Snail shell & Alluvium & Holocene \\
\hline Pharsala & FS11w & 0.7085 & 0.000015 & Water & Alluvium & Holocene \\
\hline Pharsala & FS15w & 0.7090 & 0.000017 & Water & $\begin{array}{l}\text { Lacustrine and fluvial deposits. Fossils are missing, ostracodes in } \\
\text { abundance. }\end{array}$ & Upper Pleistocene \\
\hline
\end{tabular}




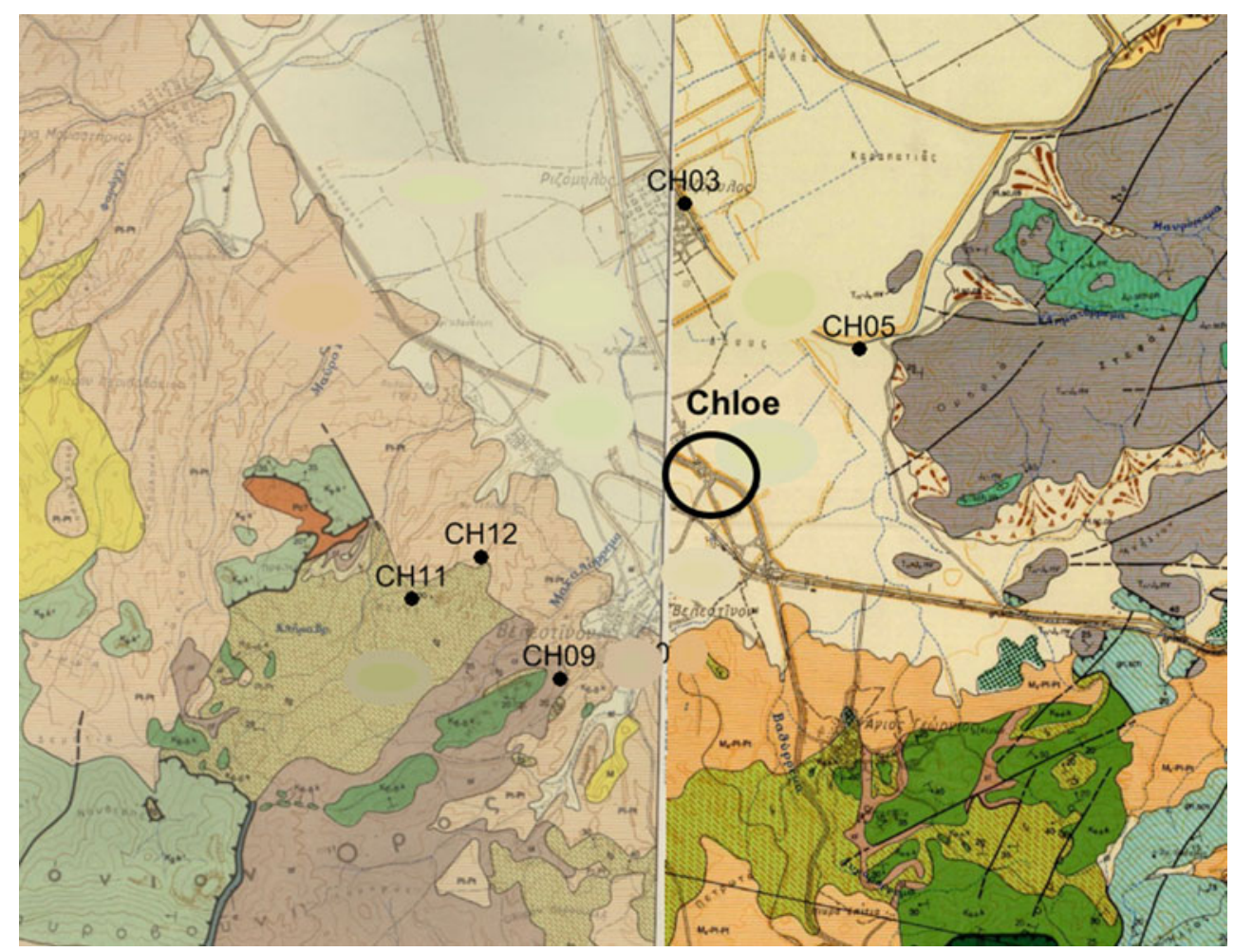

Figure 2. Geological map of Chloe (Velestino and Volos sheets) showing the location of the environmental samples.

Base map by the Institute for Geology and Subsurface Research of Greece, 1978, scale 1:50000.

TD $16 \mathrm{M} \mathrm{HNO}_{3}$ to make a three per cent $\mathrm{HNO}_{3}$ solution ready for isotope analysis by Multi-Collector ICP-MS (MC-ICPMS) using a ThermoFisher Neptune. Prior to analysis, the $\mathrm{Sr}$ fraction was tested to determine the $\mathrm{Sr}$ concentration and to ensure the major isotope of $\mathrm{Sr}\left({ }^{88} \mathrm{Sr}\right) \mathrm{did}$ not exceed the maximum voltage $(50 \mathrm{~V})$ for the detector amplifiers. Any samples that exceeded this limit were diluted to yield an ${ }^{88} \mathrm{Sr}$ signal of $\sim 25 \mathrm{~V}$.

A $\mathrm{Sr}$ isotope measurement comprised a static multi-collection routine of 1 block of 50 cycles with an integration time of 4 seconds per cycle; total analysis time: 3.5 minutes. Instrumental mass bias was corrected for by using an ${ }^{88} \mathrm{Sr} /{ }^{86} \mathrm{Sr}$ ratio of 8.375209 (the reciprocal of the accepted ${ }^{86} \mathrm{Sr} /{ }^{88} \mathrm{Sr}$ ratio of 0.1194$)$ and an exponential law. Corrections were also applied for $\mathrm{Kr}$ interferences on ${ }^{84} \mathrm{Sr}$ and ${ }^{86} \mathrm{Sr}$ and the $\mathrm{Rb}$ interference on ${ }^{87} \mathrm{Sr}$. The average ${ }^{83} \mathrm{Kr}$ intensity throughout the analytical session was $\sim 0.08 \mathrm{mV}$, which is insignificant considering the $\mathrm{Sr}$ beam size $\left({ }^{88} \mathrm{Sr}\right.$ between 13 and 29 $\mathrm{V})$. The average ${ }^{85} \mathrm{Rb}$ was slightly greater at $\sim 0.8 \mathrm{mV}$, but, given the $\mathrm{Sr}$ beam size, the correction on the ${ }^{87} \mathrm{Sr} /{ }^{86} \mathrm{Sr}$ was very small $(<0.00001)$ and is accurate.

Samples were analysed during three analytical sessions. The average ${ }^{87} \mathrm{Sr} /{ }^{86} \mathrm{Sr}$ and reproducibility for the international strontium isotope reference material NBS 987 analysed during each analytical session are reported in the Table captions. All sample data in Tables 1 and 2 are reported relative to an accepted ${ }^{87} \mathrm{Sr} /{ }^{86} \mathrm{Sr}$ ratio of 0.71024 for NBS987. 


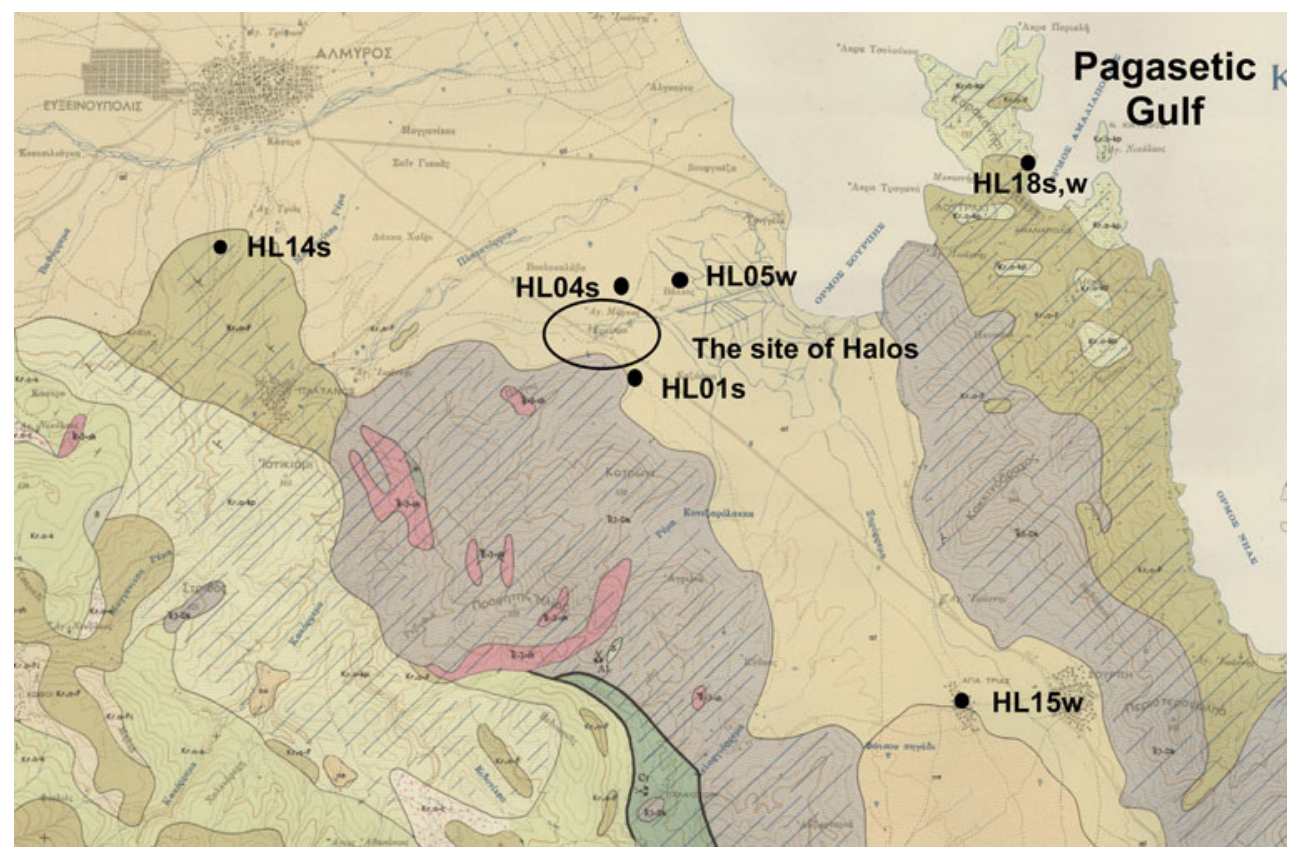

Figure 3. Geological map of Halos (Almyro sheet) showing the location of the environmental samples. Base map by the Institute for Geology and Subsurface Research of Greece, 1962, scale 1:50000.

\section{STrontium Isotope Results}

The local ${ }^{87} \mathrm{Sr} /{ }^{86} \mathrm{Sr}$ ranges have been estimated by the end-members of the environmental samples from each site. Therefore, Chloe's range is 0.7086-0.7103 $(\mathrm{n}=5)$, Voulokaliva's is $0.7078-0.7092(\mathrm{n}=7)$, and Pharsala's is $0.7078-0.7090 \quad(n=8)$. The human enamel ${ }^{87} \mathrm{Sr} /{ }^{86} \mathrm{Sr}$ values at Chloe range from 0.7089 to $0.7094(\mathrm{n}=10)$, at Voulokaliva from 0.7079 to $0.7092(n=13)$, and at Pharsala from 0.7080 to $0.7094(\mathrm{n}=$ 13). The data discussed here are presented in Tables 1 and 2. The letter beside the number of each environmental sample indicates the type of sample that has been used ('s' for snail shell and ' $w$ ' for water sample). The environmental samples represent different geological formations that could potentially have influenced the strontium isotope values of the food and water ingested by the individuals of the populations under study. In order to examine whether two or more geological end-members could have contributed to the strontium isotope values of these populations, we have also plotted human ${ }^{87} \mathrm{Sr} /{ }^{86} \mathrm{Sr}$ values against human strontium concentration $(1 / \mathrm{Sr}$ ppm *10 ${ }^{3}$ ) (Montgomery et al., 2007). Some environmental samples have yielded different ${ }^{87} \mathrm{Sr} /{ }^{86} \mathrm{Sr}$ values although they were collected from the same geological formations. This is the case where a snail shell and a water sample were collected. The reason for this difference is most probably the source of the spring water, which might have been located in a different geological formation, and thus the ${ }^{87} \mathrm{Sr} /{ }^{86} \mathrm{Sr}$ value of the water reflects the average ${ }^{87} \mathrm{Sr} /{ }^{86} \mathrm{Sr}$ values of the geological formations the water had passed through.

\section{Chloe}

The human ${ }^{87} \mathrm{Sr} /{ }^{86} \mathrm{Sr}$ values from Chloe indicate that the entire assemblage appears to be local: the human values fall within 


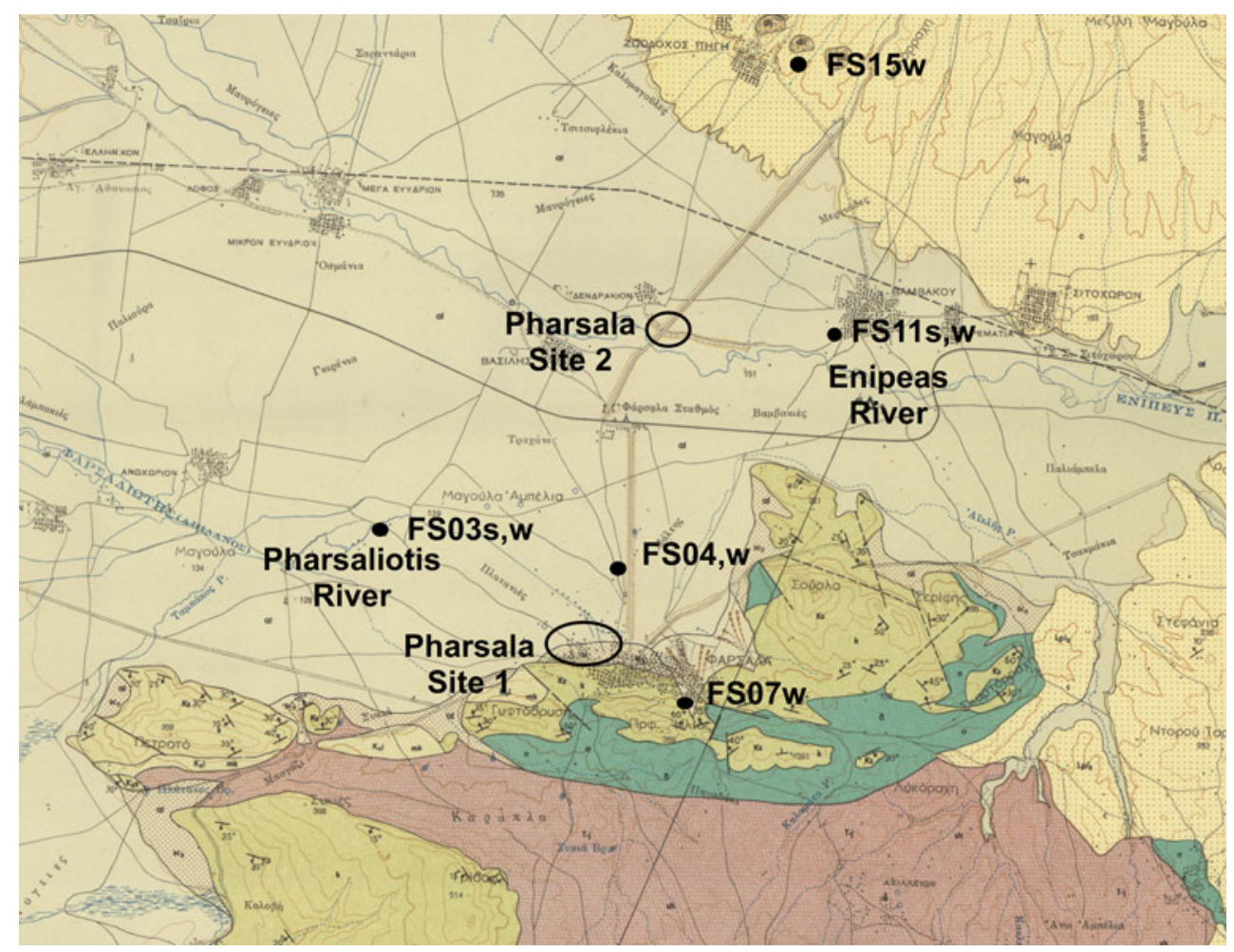

Figure 4. Geological map of Pharsala showing the location of the environmental samples.

Base map by the Institute for Geology and Subsurface Research of Greece, 1969, scale 1:50000.

the range of the environmental samples (Figure 5). As the strontium isotope ratios, with an isotopic range between the environmental samples $\mathrm{CH} 3 \mathrm{~s}, \mathrm{CH} 9 \mathrm{~s}$, and $\mathrm{CH} 12 \mathrm{~s}$, span the rain/seawater value of 0.7092 , which is an estimate of atmospheric deposition, the individuals' strontium appears to derive from more than two sources, that is two or more geological end-members and rainwater contribution to plants (Figure 5). These individuals appear to have obtained food from areas represented by the snail shell samples $\mathrm{CH} 3$ s, CH9s, and CH12s (Table 2).

The same is indicated by the plot of ${ }^{87} \mathrm{Sr} /{ }^{86} \mathrm{Sr}$ against strontium concentration $\left(1 / \mathrm{Sr}\right.$ ppm $\left.{ }^{*} 10^{3}\right)$, where no linear relationship of the entire assemblage is observed (Figure 6). The human values fall within the range from 0.7095 (CH12s) to
0.7088/0.7086 (CH03s/CH05w) (Tables 1 and 2, Figures 5 and 6). The geological formation that sample CH11s (0.7103) represents seems to make no contribution to the human strontium isotope values; the negligible difference between the dentine and the second highest snail (CH12s) suggests that the higher local end-member is best represented by the snail shell $\mathrm{CH} 12 \mathrm{~s}$ rather than the snail shell CH11s. The very small spread of the data suggests that either limestone was the main geological formation or that the ground water had flowed over limestone. Indeed, the sample $\mathrm{CH} 09$ s represents a region mainly composed by limestone and the water $\mathrm{CH} 05 \mathrm{w}$ was collected from an area close to limestone (Table 2, Figure 3); thus, the water sample yields strontium isotope values that represent those of 


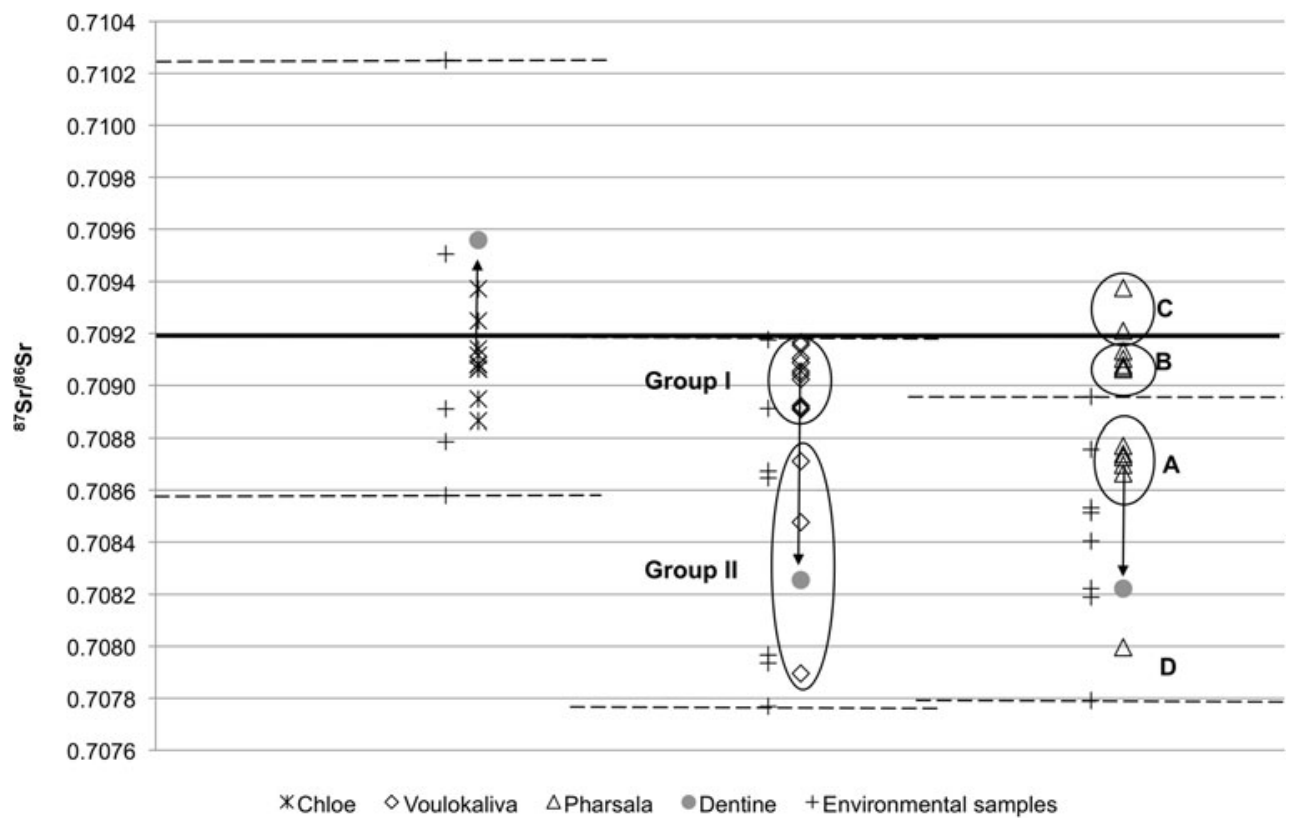

Figure 5. ${ }^{87} \mathrm{Sr}{ }^{86} \mathrm{Sr}$ ratios of the human enamel and environmental samples (local ${ }^{87} \mathrm{Sr}{ }^{86} \mathrm{Sr}$ ratios are indicated by the environmental end-members: dashed black line) from Chloe, Voulokaliva, and Pharsala. The black thick line indicates the ${ }^{87} \mathrm{Sr}{ }^{86} \mathrm{Sr}$ seawater value. The black arrow shows the enamel and the dentine of the same sample. The codes beside the environmental samples are the sample names in Table 2. The error for Sr isotopes at 2sd is within the symbol.

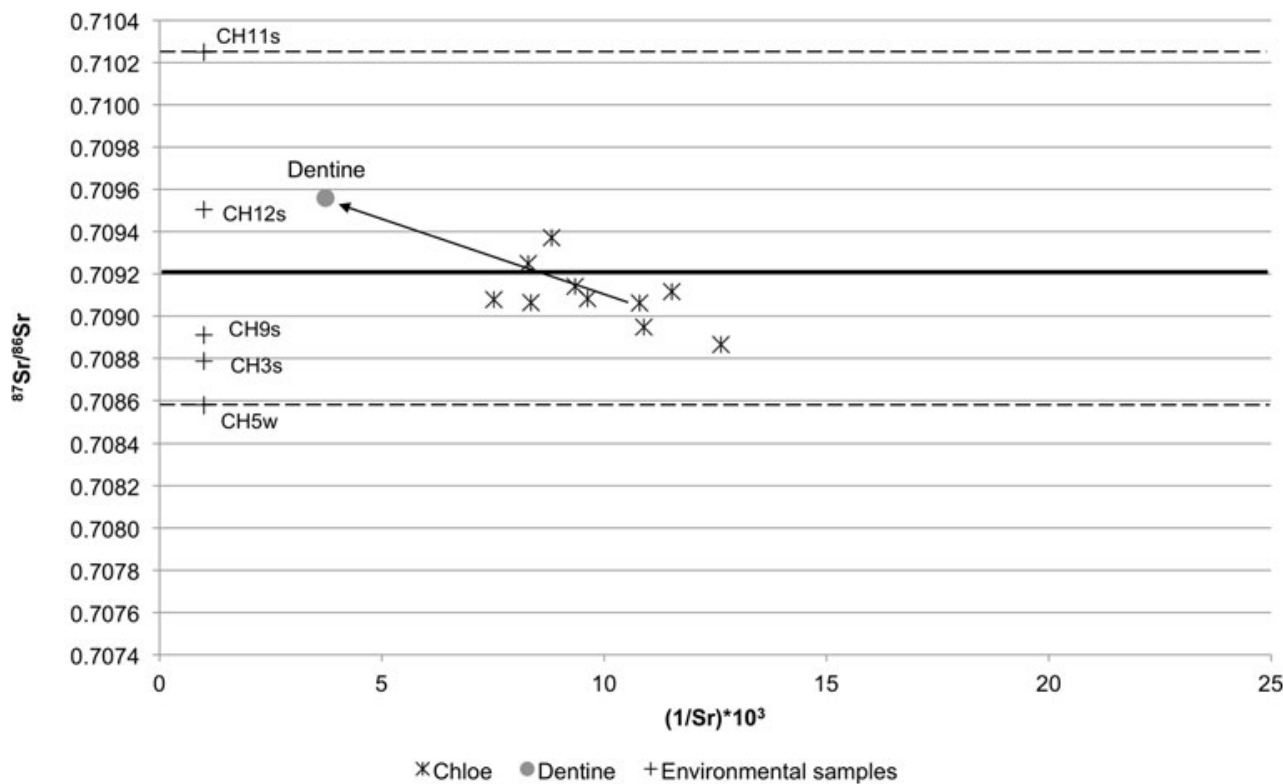

Figure 6. ${ }^{87} \mathrm{Sr}{ }^{86} \mathrm{Sr}$ ratios of human enamel and environmental samples from Chloe plotted against the $\mathrm{Sr}$ concentration of the samples. The black thick line indicates the seawater ${ }^{87} \mathrm{Sr}{ }^{86} \mathrm{Sr}$ value. The local ${ }^{87} \mathrm{Sr}{ }^{86} \mathrm{Sr}$ ratios are indicated by the environmental end-members: dashed black line. The black arrow shows the enamel and the dentine of the same sample. The error for Sr isotopes at 2sd is within the symbol. 
limestone bedrock. Geographically, we see that these environmental end-members demarcate an area that could have been used, for example, for farming (Figure 3).

\section{Voulokaliva}

The human ${ }^{87} \mathrm{Sr} /{ }^{86} \mathrm{Sr}$ values from the coastal site of Voulokaliva appear to be dominated by an upper marine end-member (via either the sea or rainfall) as the majority cluster below, but close to, 0.7092 (Figure 5). There are also a few samples (4 out of 13) yielding lower strontium isotope values, three of which separate out from the aforementioned group but are still within the local environmental range. In the plot on Figure 7, where strontium isotope data with $\mathrm{Sr}$ concentration recorded in human teeth are combined, we can see two groups of samples (Group I and Group II).

Group I must have used a region restricted between the sea value $(0.7092)$ and limestone (0.7089). Both these endmembers represent samples collected in the same location (seawater and snail shell). Group II belongs to an area between limestone (0.7089) and sedimentary rocks (0.7078) (Table 2, Figure 4). Although this location is only $3 \mathrm{~km}$ from the coast, the contribution from the sea seems to be limited, possibly because a low mountain stands between the two areas.

The individuals from Voulokaliva all appear to be local, but with differences in food origin. All the environmental samples are sourced locally; the water samples came from springs on the mountain of Sourpi, located to the west of the area of

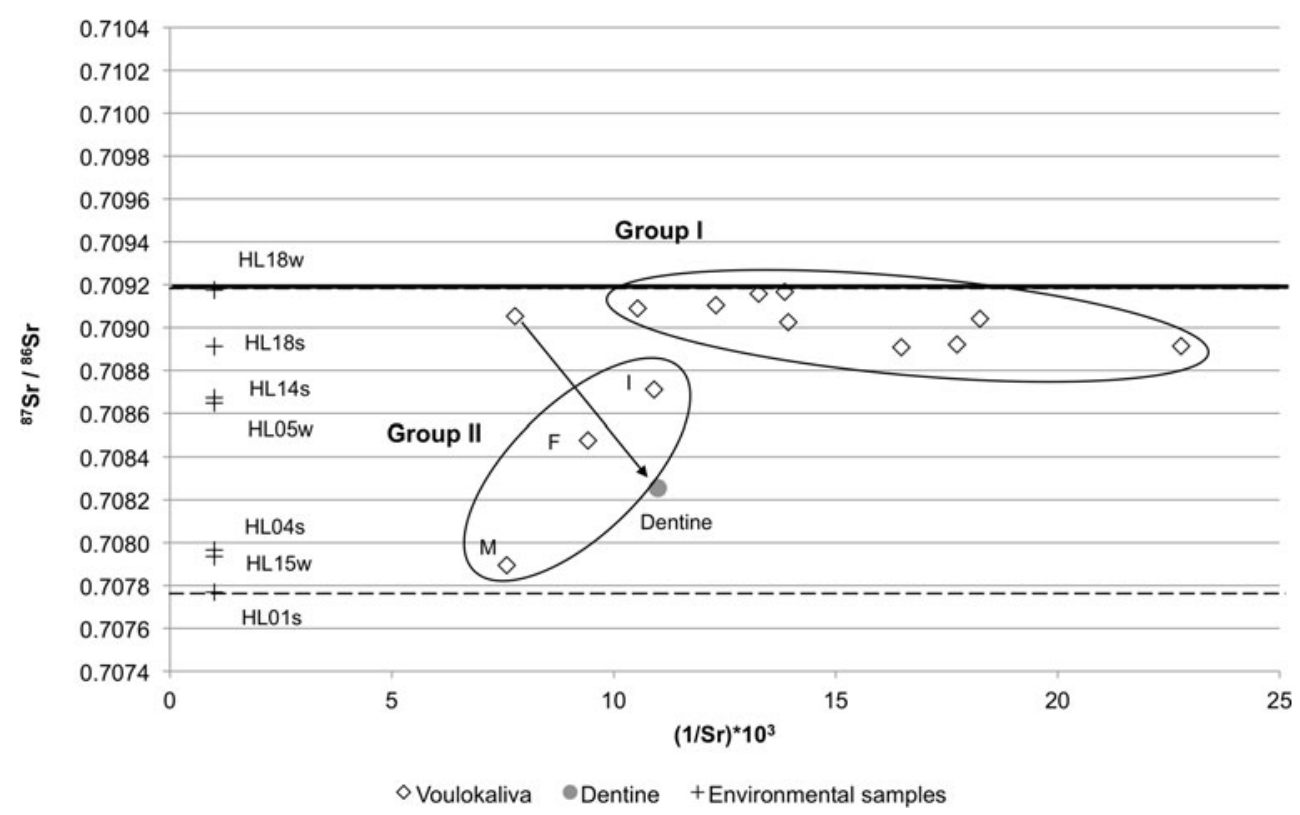

Figure 7. ${ }^{87} \mathrm{Sr}{ }^{86} \mathrm{Sr}$ ratios of human enamel and environmental samples from Voulokaliva plotted against the Sr concentration of the samples. The black thick line indicates the seawater ${ }^{87} \mathrm{Sr}{ }^{86} \mathrm{Sr}$ value. The local ${ }^{87} \mathrm{Sr}{ }^{86} \mathrm{Sr}$ ratios are indicated by the environmental end-members: dashed black line. The black arrow shows the enamel and the dentine of the same sample. The letters $M, F$, and I indicate the sex of the individuals from which these samples were taken (M: Male, F: Female, I: Indeterminate sex). The codes beside the environmental samples are the sample names in Table 2. The error for $S r$ isotopes at 2sd is within the symbol. 
Halos. The majority is mainly influenced by the coastal environment, but also by limestone. The three samples that do not fit in this restricted area on the plot probably derive from people settled in the region of Halos on sedimentary formations or who obtained their food from a region whose ${ }^{87} \mathrm{Sr} /{ }^{86} \mathrm{Sr}$ values are not influenced by the sea.

\section{Pharsala}

The human ${ }^{87} \mathrm{Sr} /{ }^{86} \mathrm{Sr}$ values from Pharsala clearly indicate two distinct groups (Figure 5). One group (A), with lower ${ }^{87} \mathrm{Sr} /{ }^{86} \mathrm{Sr}$ values, lies within the local environmental range, while a second group (B), with higher ${ }^{87} \mathrm{Sr} /{ }^{86} \mathrm{Sr}$ values, lies outside this local range. Three more human samples are outliers. Group C, a female and an indeterminate individual yielding the highest values, lies above seawater and higher than the environmental range. Another individual (D), a female, is within the environmental range but significantly different from any of the other individuals from Pharsala.

The plot that presents ${ }^{87} \mathrm{Sr} /{ }^{86} \mathrm{Sr}$ isotope values against strontium concentration (1/ Sr ppm *10 ${ }^{3}$ ) strengthens the case for outliers at Pharsala (Figure 8). Group A, identified as local, between the two endmembers FS15w (0.7090, lacustrine deposits) and FS04w/FS11s (0.7082/ 0.7088, alluvium deposits), appears to have used the valley and the water of the river Enipeas to produce their food. The river Apidanos (FS03s,w) probably did not influence the isotopic range of human group A, which exhibits a significant difference (Table 2, Figure 4). In contrast, the individuals of group $\mathrm{B}$, who were also

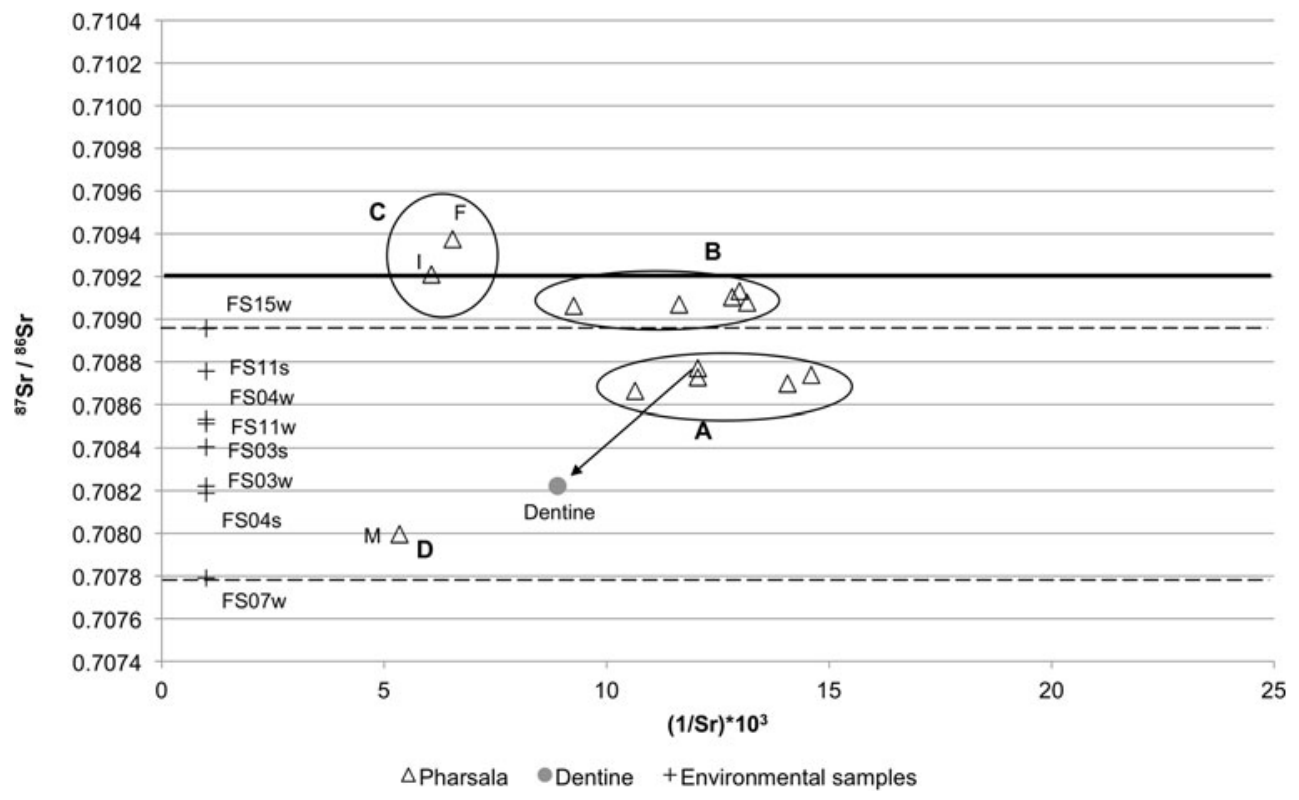

Figure $8 .{ }^{87} \mathrm{Sr}{ }^{86} \mathrm{Sr}$ ratios of human enamel and environmental samples from Pharsala plotted against the $\mathrm{Sr}$ concentration of the samples. The black thick line indicates the seawater ${ }^{87} \mathrm{Sr}{ }^{86} \mathrm{Sr}$ value. The local ${ }^{87} \mathrm{Sr}{ }^{86} \mathrm{Sr}$ ratios are indicated by the environmental end-members: dashed black line. The black arrow shows the enamel and the dentine of the same sample. The letters $F$, and I indicate the sex of the individuals from which these samples were taken (F: Female, I: Indeterminate sex). The codes beside the environmental samples are the sample names in Table 2. The error for Sr isotopes at 2sd is within the symbol. 
buried in the same area, seem to have consumed in their youth food grown in an area with a geological substrate that is not present in this geological framework and, therefore, not represented by any environmental sample (be it water or snail shell) taken for this study.

Individual $\mathrm{D}$ can be considered local because an environmental sample provides a very low ${ }^{87} \mathrm{Sr} /{ }^{86} \mathrm{Sr}$ value $(\mathrm{FS} 07 \mathrm{w}=$ 0.7078). This water sample has been collected from an area that is close to ophiolite (volcanic rock) with low ${ }^{87} \mathrm{Sr} /{ }^{86} \mathrm{Sr}$ values. This spring water represents the isotope values of the food and water ingested by this individual from such a geological formation. Furthermore, the dentine, which is prone to post-mortem uptake of soil strontium during burial and, thus, provides an indication of the local environment (Montgomery et al., 2007), has very low ${ }^{87} \mathrm{Sr} /{ }^{86} \mathrm{Sr}$ values and is very close to the enamel ${ }^{87} \mathrm{Sr} /{ }^{86} \mathrm{Sr}$ value of individual $\mathrm{D}$, indicating that this individual is local. However, because snail shells from this ophiolite formation have not been analysed, we cannot discuss the origin of the strontium of this individual in more detail.

Human groups B and C are considered non-local. Group B exhibits values similar to seawater and could indicate a group of coastal origin, like Voulokaliva. On the other hand, the humans from Chloe, which is not close to the sea, also exhibit values comparable to seawater values (Figure 5). The mixing of two or more geological sources coupled with atmospheric deposition in the form of rainwater may produce an average value that is close to, but has no connection with, seawater. Given this equifinality of the data and sources, it is not possible to identify a place of origin for the individuals in these groups, nor to associate them definitely with Vouloklaiva or Chloe. Lastly, the outliers of group $\mathrm{C}$ originate from a region with high $\mathrm{Sr}$ biosphere values, which are not supported by the local bedrock of Pharsala or any other site included in this study.

\section{Population Movements in the Early Iron AGE}

Chloe's environmental and human results as well as the archaeological data support each other well. The narrow spread of human strontium isotope values around the mean environmental value suggests that the group represented by these data had potentially explored most of the surrounding food and water sources over a distance of some $5 \mathrm{~km}$, as mentioned in the sampling paragraph above. This group also shared funerary customs following the traditional Mycenaean way, which suggests that perhaps they shared the same cultural background and social status as well, in other words that they were continuing local practices.

The majority of the humans from Voulokaliva lie mostly around the seawater value, as expected in a coastal population (Bentley, 2006). In contrast, the three individuals with lower values indicate a reduced marine contribution and values that are dominated by either ophiolites or limestones. The two lowest values $(12-\mathrm{HaVo} /$ $\mathrm{w}-\mathrm{c} 7 / \mathrm{ind} 2$ and $13-\mathrm{HaVo} / \mathrm{w}-\mathrm{c} 7 / \mathrm{ind} 1)$ belong to two individuals (a male and a female) who were buried together in a cist of the Sub-Mycenaean period. A third individual $(11-\mathrm{HaVo} / \mathrm{e}-\mathrm{cc} 8 / \mathrm{ind} 1)$ was buried in a circular construction of the Early Protogeometric period. Based on the pottery sequence, the individuals with the lowest values are represented in the earliest burials. This could indicate either a change in land exploitation from the SubMycenaean period to the Protogeometric or a move from sedimentary rocks to a location closer to the coast (HL18). Since the Early Iron Age is a period still inadequately studied, we cannot (yet) decide in favour of one or the other alternative. 
The two groups (A and B) detected by strontium isotope analysis at Pharsala are also identifiable in the archaeological evidence. While the individuals of group A were buried in Site 1, the individuals of group B were buried in the distant tholoi of Site 2. However, only the burial location suggests a difference between these isotopically distinct groups. Other aspects of burial practices, such as tomb types and treatment, are similar in both burial groups, suggesting that, although group B consisted of non-locals, they came from a culturally comparable region.

The lower strontium isotope value (D), supported by a sole water sample, could indicate residence or use of foods produced in this area because no other geological formation in the valley yielded such a low value. Alternatively, this could be a nonlocal individual that coincidentally exhibited local values. This individual is a female, buried under a tumulus in the cemetery among local individuals, and is not differentiated from group A. The same occurs for the two high outliers (group C). They were both buried in Site 1 among locals; one was a female in a burial enclosure and the other an indeterminate individual in a cist. These three individuals may provide evidence for the practice of exogamy (because of their non-local provenance), but nevertheless were apparently integrated within the local community.

\section{Conclusions}

The observations and conclusions of the strontium isotope analysis indicate that the three sites in Thessaly show clear human isotopic groups, although there are overlaps of ${ }^{87} \mathrm{Sr} /{ }^{86} \mathrm{Sr}$ environmental values between the sites. Chloe appears to provide evidence of indigenous burials. In contrast, while Voulokaliva appears to consist largely of local individuals, the archaeological and isotopic evidence suggests that three individuals from the Sub-Mycenaean and Early Protogeometric period were obtaining foods from the wider area of Halos or came from elsewhere within that area. In Pharsala, on the other hand, non-local individuals have been detected, possibly originating from a region that is geologically and isotopically, but not necessarily culturally, distinguishable. These individuals were buried among locals as well as in separate locations.

The method we have employed to answer the questions set out at the beginning of this article has identified individuals of non-local origin and movement either within the same region or even over longer distances during the Early Iron Age. However, the place of origin of these people is not easily distinguishable, and it is very difficult to reach definite conclusions, especially in a region with such a diverse geological history and bedrock but a limited range of biosphere strontium isotopes. What is surprising, perhaps, is that, even in this geological setting, clear isotopic groupings of humans are detectable. This suggests that the groups at Voulokaliva and Pharsala followed formalized and geographically constrained food production and procurement strategies. Exhaustive studies of the geological formations of likely areas, along with a more systematic archaeological investigation of possible regions of origin, are clearly necessary.

Our integrated analysis revealed another interesting practice. A group of non-locals in Pharsala was buried in a traditional Mycenaean manner and not in an innovative way, as might be expected. In Chloe, on the other hand, traditional Mycenaean burial rites were practised by locals. Therefore, the newcomers could have come from a region not necessarily very far from, or outside, Thessaly, and possibly culturally similar. However, we cannot definitely exclude the possibility that these individuals were claiming status and kin relations 
through the adoption of traditional funerary practices. In addition, the presence of newcomers does not necessarily indicate change in the local tradition. It appears that cultural assimilation must have occurred to some extent. Three potentially non-local individuals in Pharsala were buried in graves alongside locals, indicating perhaps that they or their descendants had adopted local funerary and cultural practices.

As to the individuals buried with innovative practices, they are consistent with local origins, but the equifinality inherent in strontium isotope data means that origins elsewhere in a region characterized by the same isotope ratios cannot be definitively ruled out. The diversity observed among the local populations indicates that social variation and differentiation could have played a significant role here. This aspect has been extensively discussed by Panagiotopoulou et al. (2016) and Panagiotopoulou et al. (forthcoming). The present article provides the first evidence of burial diversity associated with the presence of individuals of different geographical provenance. Large-scale population movements have not been detected; and mobility among these populations was likely to have been rather smaller-scale, reflecting the movement of individuals or families. The presence of both local and non-local individuals in the same community is evident in the great diversity of Early Iron Age burial practices. The non-locals, however, did not necessarily bring about a change from traditional to new practices. Rather, they indicate that small-scale movement took place in the Early Iron Age for various purposes, such as exogamy or, perhaps, the relocation of entire families, potentially within a common cultural environment.

\section{Acknowledgments}

The authors would like to thank INSTAP (Institute of Aegean Prehistory) for funding the analysis presented here. Furthermore, we thank the Stichting Philologisch Studiefonds Utrecht for funding a research trip to Greece to collect the archaeological data and the environmental samples. Last, but not least, we acknowledge the cooperation of the people from the local offices of the Greek Archaeological Service and the permits granted to access and sample the material for this project.

\section{REFERENCES}

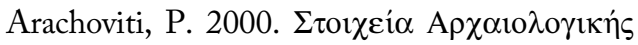

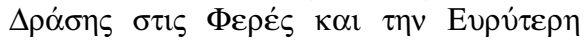

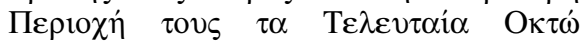
Xpóvio. In: P. Kalogerakou, ed. $1 \eta$

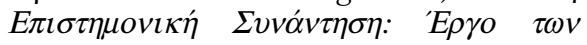

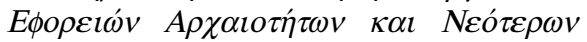

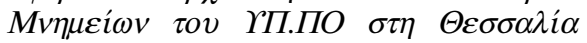

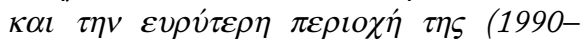
1998). Volos: Ministry of Culture, pp. $355-71$.

Bentley, A.R. 2006. Strontium Isotopes from the Earth to the Archaeological Skeleton: A Review. Journal of Archaeological Method and Theory, 13: 135-87.

Coldstream, N.J. 2003. Geometric Greece 900700 BC. London: Routledge.

Danalatos, N.G. 1992. Quantified Analysis of Selected Land Use Systems in the Larissa Region, Greece (unpublished $\mathrm{PhD}$ dissertation, Wageningen Agricultural University).

Darby, H.C. 1944. Physical Geography, History, Administration and People: Greece (Geographical Handbook Series, I). London: HMSO.

Desborough, V.R. d'A. 1964. The Last Mycenaeans and their Successors: An Archaeological Survey, c. 120--c. 1000 BC. Oxford: Oxford University Press.

Desborough, V.R. d'A. 1972. The Greek Dark Ages. London: Benn.

Dickinson, O. 2006. The Aegean from Bronze Age to Iron Age. London \& New York: Routledge.

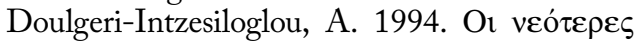

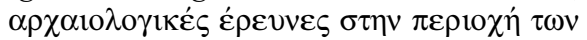

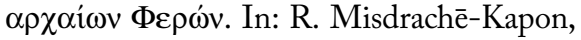
ed. La Thessalie: quinze années de recherches 
archéologiques, 1975-1990, bilans et perspectives, Lyon 17-22 avril 1990. Athens: Hellenic Ministry of Culture, pp. 71-92.

Doulgeri-Intzesiloglou, A. 1996. Пврьохиं

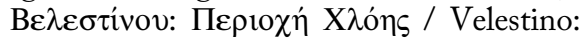
region of Chloe. Archaeologiko Deltio, 51: 343-44.

Doulgeri-Intzesiloglou, A. \& Arachoviti, P.

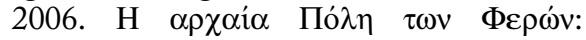

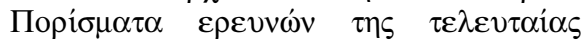

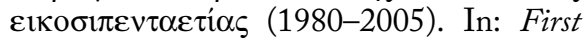
International Congress on the History and Culture of Thessaly, 9-11 November 2006. Larisa: Periphery of Thessaly, pp. 233-43.

Evans, J.A., Montgomery, J. \& Wildman, G. 2009. Isotope Domain Mapping of ${ }^{87} \mathrm{Sr} /{ }^{86} \mathrm{Sr}$ Biosphere Variation on the Isle of Skye, Scotland. Journal of the Geological Society, 166: 617-31.

Georganas, I. 2008. Between Admetus and Jason: Pherai in the Early Iron Age. In: C. Gallou, M. Georgiadis \& G.M. Muskett, eds. Dioskouroi: Studies Presented to W.G. Cavanagh and C.B. Mee on the Anniversary of their 30-Year Joint Contribution to Aegean Archaeology (BAR International Series 1889). Oxford: Archaeopress, pp. 274-80.

Georganas, I. 2009. Dying in Early Iron Age Thessaly. In: A. Mazarakis-Ainian \& A. Doulgeri-Intzesiloglou, eds. 2nd Archaeological Work on Thessaly and Central Greece 20032005: From Prehistory to the Contemporary Period. Volos: University of Thessaly, pp. 195-231.

Hall, J.M. 1997. Ethnic Identity in Greek Antiquity. Cambridge: Cambridge University Press.

Hartman, G. \& Richards, M.P. 2014. Mapping and Defining Sources of Variability in Bioavailable Strontium Isotope Ratios in the Eastern Mediterranean. Geochimica et Cosmochimica Acta, 126: 250-64.

Higgins, M.D. \& Higgins, R. 1996. A Geological Companion to Greece and the Aegean, London: Duckworth.

Institute for Geology and Subsurface Research of Greece, Map of geological substrate, Almyros sheet, 1962.

Institute for Geology and Subsurface Research of Greece, Map of geological substrate, Pharsala sheet, 1969.

Institute for Geology and Subsurface Research of Greece, Map of geological substrate, Velestino sheet and Volos sheet, 1978.

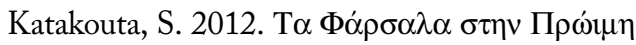

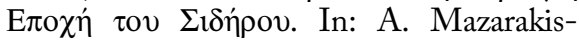
Ainian, ed. 3rd Archaeological Work on Thessaly and Central Greece 2006-2008: From Prehistory to the Contemporary Period. Volos: University of Thessaly, pp. 241-50.

Lemos, I.S. 2002. The Protogeometric Aegean: The Archaeology of the Eleventh and Tenth Centuries BC. Oxford: Oxford University Press.

Lis, B., Batziou-Efstathiou, A., Rückl, Š., Kiriatzi, E., Müller, N. 2015. Tracing Mobility in Prehistoric Central Greece. Unpublished paper given at the 5th Archaeological Meeting of Thessaly and Central Greece 2012-2014: From Prehistory to the Contemporary Period, Volos, Greece, 26 February-1 March 2015.

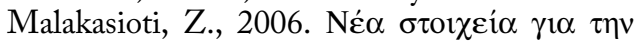

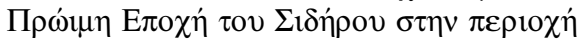

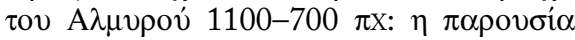

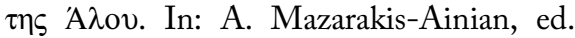
Archaeological Work on Thessaly and Central Greece: From Prehistory to the Contemporary Period, 16-19 March 2006. Volos: University of Thessaly, pp. 111-21.

Montgomery, J. 2010. Passports from the Past: Investigating Human Dispersals Using Strontium Isotope Analysis of Tooth Enamel. Annals of Human Biology, 37: 325-46.

Montgomery, J., Evans, J.A. \& Cooper, R.E. 2007. Resolving Archaeological Populations with Sr-Isotope Mixing Models. Applied Geochemistry, 22: 1502-14.

Morris, I. 2007. Early Iron Age Greece. In: W. Scheidel, I. Morris \& R.P. Saller, eds. Cambridge Histories Online: The Cambridge Economic History of the Greco-Roman World. Cambridge: Cambridge University Press, pp. 211-41.

Nafplioti, A. 2011. Tracing Population Mobility in the Aegean Using Isotope Geochemistry: A First Map of Local Biologically Available ${ }^{87} \mathrm{Sr} /{ }^{86} \mathrm{Sr}$ Signatures. Journal of Archaeological Science, 38: 1560-70.

Orfanou, V. 2015. Early Iron Age Greece, Ancient Pherae and the Archaeometallurgy of Copper. In: Z. TheodoropoulouPolychroniadis \& E. Evely, eds. Aegis: Essays in Mediterranean Archaeology: Presented to Matti Egon by the Scholars of the Greek Archaeological Committee UK. Oxford: Archaeopress, pp. 107-16. 
Panagiotopoulou, E. \& Papathanasiou, A. 2015. Dietary Reconstruction at the Geometric Period Burial Site of Agios Dimitrios in Central Greece. In: A. Papathanasiou, M.P. Richards \& S.C. Fox, eds. Archaeodiet in the Greek World: Dietary Reconstruction from Stable Isotope Analysis. Princeton (NJ): The American School of Classical Studies at Athens, pp. 105-17.

Panagiotopoulou, E., van der Plicht, J., Papathanasiou, A., Voutsaki, S., Nikolaou, E. \& Tsiouka, F. 2016. Isotopic $\left({ }^{13} \mathrm{C},{ }^{15} \mathrm{~N}\right)$ Investigation of Diet and Social Structure in Early Iron Age Halos, Greece. Journal of Archaeological Science: Reports, 10: 212-20.

Panagiotopoulou, E., van der Plicht, J., Papathanasiou, A., Voutsaki, S., Katakouta, S., Doulgeri-Intzesiloglou, A., et al. forthcoming. Diet and Social Divisions in Protohistoric Greece: Integrating Analyses of Stable Isotopes and Mortuary Practices. Journal of Greek Archaeology, 3.

Papathanasiou, A., Panagiotopoulou, E., Beltsios, K., Papakonstantinou, M.F. \& Sipsi, M. 2013. Inferences from the Human Skeletal Material of the Early Iron Age Cemetery at Agios Dimitrios, Fthiotis, Central Greece. Journal of Archaeological Science, 40: 2924-33.

Price, T.D., Burton, J.H. \& Bentley, A.R. 2002. The Characterization of Biologically Available Sr Isotope Ratios for the Study of Prehistoric Migration. Archaeometry, 44: 117-35.

Price, T.D., Johnson, C.M., Ezzo, J.A., Ericson, J. \& Burton, J.H. 1994. Residential Mobility in the Prehistoric Southwest United States: A Preliminary Study Using Strontium Isotope Analysis. Journal of Archaeological Science, 21(3): 315-30.

Reinders, R.H. 2003. Beginning and End of the Occupation of New Halos. In: R.H. Reinders \& W. Prummel, eds. Housing in New Halos: A Hellenistic Town in Thessaly, Greece. Lisse: A.A. Balkema Publishers, pp. 231-47.

Richards, M., Harvati, K., Grimes, V., Smith, C., Smith, T., Hublin, J.J., et al. 2008. Strontium Isotope Evidence of Neanderthal Mobility at the Site of Lakonis, Greece, Using Laser Ablation PIMMS. Journal of Archaeological Science, 35: 1251-56.

Rückl, ک̌. 2014. "Pots = Potters": Translocal and Travelling Technologies in Early Iron
Age Halos (Thessaly). Unpublished paper given at the NPAP Final Conference, Integrated Approaches to Ceramic Analysis and Methodology from a TransRegional Perspective, University of Amsterdam, 11-13 December 2014.

Snodgrass, A.M. 2000. The Dark Age of Greece: An Archaeological Survey of the Eleventh to the Tenth Centuries $B C$ (2nd ed). Edinburgh: Edinburgh University Press.

Snodgrass, A.M. 2006. Archaeology and the Emergence of Greece. Ithaca: Cornell University Press.

Stallo, J.R., Schepartz, L.A., Grimes, V. \& Richards, M.P. 2010. Strontium Isotope Ratios and Mobility Reconstruction. In: M.G. Amore, ed. The Complex of Tumuli 9, 10 and 11 in the Necropolis of Apollonia (Albania) (International Centre for Albanian Archaeology Monograph Series 2). Oxford: Archaeopress, pp. 78-84.

Stissi, V., Kwak, L. \& de Winter, J. 2004. Early Iron Age. In: R. Reinders, ed. Prehistoric Sites at the Almiros and Sourpi Plains (Thessaly, Greece). Assen: Van Gorcum, pp. 94-98.

Toffolo, M.B., Fantalkin, A., Lemos, I.S., Felsch, R.C.S., Niemeier, W.D., Sanders, G.D.R., et al. 2013. Towards an Absolute Chronology for the Aegean Iron Age: New Radiocarbon Dates from Lefkandi, Kalapodi and Corinth. PLoS ONE, 8: e83117. https://doi.org/10.1371/ journal.pone.0083117.

Triantaphyllou, S. 2015. A Stable Isotope Analysis of Skeletal Assemblages from Prehistoric Northern Greece. In: A. Papathanasiou, M.P. Richards \& S.C. Fox, eds. Archaeodiet in the Greek World: Dietary Reconstruction from Stable Isotope Analysis. Princeton (NJ): The American School of Classical Studies at Athens, pp. 57-75.

Tziafalias, A. \& Batziou-Efstathiou, A. 2010.

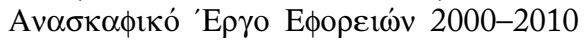

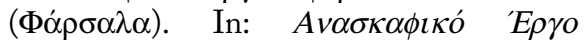

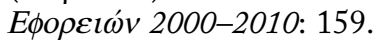

Whitley, J. 1991. Social Diversity in Dark Age Greece. Annual of the British School at Athens, 86: 341-65.

Wright, L.E. 2005. Identifying Immigrants to Tikal, Guatemala: Defining Local Variability in Strontium Isotope Ratios of Human Tooth Enamel. Journal of Archaeological Science, 32: 555-66. 


\section{Biographical Notes}

Eleni Panagiotopoulou attended the Chemistry and Material Science MSc programme at the University of Ioannina in Greece, where she focused on analytical methods for human remains to investigate crucial archaeological questions. In her $\mathrm{PhD}$ research, she combined the isotope analysis of human tissues for diet reconstruction and population movements with the contextual analysis of mortuary data to investigate the social structure in Early Iron Age Greece.

Address: Eleni Panagiotopoulou, Institute of Archaeology, University of Groningen, Poststraat 6, 9712ER, Groningen, The Netherlands. [email: e.panagiotopoulou@ rug.nl]

Janet Montgomery is an Associate Professor (Reader) in Archaeological Science at the Department of Archaeology, Durham University. She obtained her NERC-funded doctorate in 2002 at the University of Bradford, focusing on the application of combined radiogenic lead and strontium isotope analysis to British archaeological humans. She has been a NERC Postdoctoral Fellow and Lecturer in Archaeological Science at the University of Bradford.

Address: Janet Montgomery, Department of Archaeology, Durham University, Durham, DH1 3LE, UK. [email: janet. montgomery@durham.ac.uk]

Geoff Nowell is a Senior Research Officer in the Department of Earth Sciences at Durham University. He gained his $\mathrm{PhD}$ in 1993 and, until his present position, he has worked as a postdoctoral researcher and scientific officer at Durham
University, the NERC Isotope Geosciences Laboratories (NIGL), and the University of Bristol. He is a specialist in multi-collector plasma ionization and thermal ionization mass spectrometry.

Address: Geoff Nowell, Department of Earth Sciences, Durham University, South Road, Durham, DH1 3LE, UK. [email: g.m.nowell@durham.ac.uk]

Joanne Peterkin is a Research Laboratory Technician at the Department of Earth Sciences at Durham University. Her MSc was on Environmental Biogeochemistry at Tyne University, Newcastle.

Address: Joanne Peterkin, Department of Earth Sciences, Durham University, South Road, Durham, DH1 3LE, UK. [email: j.1. peterkin@dur.ac.uk]

Argiro Doulgeri-Intzesiloglou is Director Emerita of the Ephorate of Antiquities of Magnesia and the excavator and researcher of the site of Chloe. Her $\mathrm{PhD}$ research was on Thessalian epigraphy.

Address: Argiro Doulgeri-Intzesiloglou, Hellenic Ministry of Culture, Ephorate of Antiquities of Magnesia, Athanasaki 1, 380 01, Volos, Greece. [email: bab.arg. intzesiloglou@gmail.com]

Polixeni Arachoviti is an archaeologist working in the Ephorate of Antiquities of Magnesia and the excavator and researcher of the site of Chloe.

Address: Polixeni Arachoviti, Hellenic Ministry of Culture, Ephorate of Antiquities of Magnesia, Athanasaki 1, 380 01, Volos, Greece. [email: polaracho viti@gmail.com] 
Stiliani Katakouta is an archaeologist working in the Ephorate of Antiquities of Larisa and the excavator and researcher of the site of Pharsala. Her current $\mathrm{PhD}$ research is on Hellenistic Greece.

Address: Stiliani Katakouta, Hellenic Ministry of Culture, Ephorate of Antiquities of Larisa, Mezourlo, 41500, Larisa, Greece. [email: stefodas@yahoo.gr]
Fotini Tsiouka is an archaeologist working in the Ephorate of Antiquities of Karditsa and the excavator and researcher of the site of Voulokaliva. Her MA dissertation was on the Early Iron Age burial practices of Voulokaliva.

Address: Fotini Tsiouka, Hellenic Ministry of Culture, Ephorate of Antiquities of Karditsa, Loukianou 1, 431 00, Karditsa, Greece. [email: ftsiouka@hotmail.com]

\section{L'analyse des isotopes du strontium au service de la recherche sur la mobilité en Thessalie à l'âge du Fer}

Dans cet article nous examinons les données concernant les mouvements de population en Thessalie en Grèce au début de l'âge du Fer (époque protogéométrique, XIe-LXe siècles av. J.-C.). La méthode choisie pour déceler la présence d'individus allochtones est l'analyse des isotopes du strontium $\left.{ }^{87} \mathrm{Sr} /{ }^{86} \mathrm{Sr}\right)$ préservé dan l'email dentaire combinée ici avec une analyse contextuelle des pratiques funéraires et l'analyse ostéologique des restes humains. L'époque protogéométrique vit une série de transformations sociales et culturelles alors que la société se remettait de la désintégration de la civilisation mycénienne (XIIe siècle av. J.-C.). L'étude des nécropoles de Voulokaliva, Chloe et Pharsala en Thessalie méridionale démontre que des individus étrangers intégrés aux communautés étudiées ont contribué à la diversité des pratiques funéraires et ont ainsi participé à l'évolution de l'organisation sociale. Translation by Madeleine Hummler

Mots-clés: âge du Fer ancien, analyses des isotopes du strontium, mouvements de population, Thessalie

\section{Die Erkennung der Bevölkerungsmobilität in Thessalien in der frühen Eisenzeit durch die Analyse der Strontium Isotopen}

In diesem Artikel werden die Angaben über Bevölkerungsbewegungen in Thessalien in Griechenland in der früheisenzeitlichen protogeometrischen Periode (11. bis 9. Jh. v. Chr.) untersucht. Die Methode, die wir gewählt haben, um nicht-einheimische Individuen zu erkennen, ist die Analyse von ${ }^{87} \mathrm{Sr} /{ }^{86} \mathrm{Sr}$ Strontium Isotopen im Zahnschmelz. Diese Untersuchung wird hier mit einer kontextuellen Auswertung der Bestattungssitten und einer Analyse der menschlichen Skelettreste verbunden. In protogeometrischer Zeit haben mehrere soziale und kulturelle Veränderungen stattgefunden, als die Gesellschaft sich vom Zerfall der mykenischen Zivilisation (12. Jh. v. Chr.) erholte. Die Auswertung der Gräberfelder von Voulokaliva, Chloe und Pharsala im Süden von Thessalien hat gezeigt, dass die nicht-einheimischen Individuen in diesen Gemeinschaften zur Vielfalt der Bestattungssitten und zur Entwicklung der sozialen Organisation der Gesellschaft beigetragen haben. Translation by Madeleine Hummler

Stichworte: frühe Eisenzeit, Griechenland, Analyse der Strontium Isotopen, Bevölkerungsbewegungen, Thessalien 